\title{
Effect of growth intensity of bulls on the microstructure of musculus longissimus lumborum and meat quality
}

\author{
Krzysztof Młynek ${ }^{1}$, Izabela Janiuk², Alicja Dzido ${ }^{1}$ \\ ${ }^{1}$ Department of Cattle Breeding and Milk Evaluation ${ }^{2}$ Department of Vertebrate Morphology, Siedlce University
} of Natural Science and Humanities, Poland

Received September 14, 2010

Accepted March 7, 2012

\begin{abstract}
The aim of this study was to evaluate the effect of growth intensity of 43 bulls with different growth intensity $(<900$ and $\geq 900 \mathrm{~g}$ /day) on the microstructure of musculus longissimus lumborum. Commercial crosses of Polish Lowland black-and-white cows with Charolais and Limousin bulls were used in this study; within the particular genetic groups the hybrids had similar slaughter weight (447.6 and $517.2 \mathrm{~kg}$ ) and age (526 and 606 days), respectively. The share of fibres with active tetrazole dehydragenase in the more intensively growing animals was smaller. For fibres with myofibrillar ATPase activity, the intensively growing animals produced higher standard deviation values than the other groups. Further analysis of the muscular tissue in this group revealed that out of the 24 muscles, 9 had giant fibres. In comparison with the less intensively growing animals, the muscles of the bulls that gained more than $900 \mathrm{~g} /$ day in weight were found to contain significantly less glycogen $(P \leq 0.01)$ and, consequently, the meat was less acidic. The difference of the $\mathrm{pH}$ ranged from 0.19 in the case of $\mathrm{pH}_{24}(P \leq 0.01)$ to 0.06 for $\mathrm{pH}_{48}$ $(P \leq 0.01)$. It should be noted that the intensively growing animals were found to have a relatively high $\mathrm{pH}$ variability $\left(\mathrm{SD}=0.69\right.$ and 0.49 , respectively). The $\mathrm{pH}_{24}$ and $\mathrm{pH}_{48}$ values, as well as $\mathrm{pH}$ variability show that the meat of this group was dark, firm and dry.
\end{abstract}

Daily body gain, beef, histological traits, meat faults

One of the most effective methods to increase beef production is using commercial cross-breeding for which Charolais and Limousin bulls are predominantly used at present. On the other hand, satisfactory results could be obtained with production efficiency and the possibility of using growth-intensifying feeds for fattening the hybrids. Growth intensity and commercial cross-breeding significantly affect the formation muscle microstructure and muscle metabolism. As a result, the processing and cooking usefulness of meat can be enhanced (Ozawa et al. 2000; Vestergaard et al. 2000; Wegner et al. 2000; Młynek and Guliński 2007).

Meat quality is predominantly affected by the feeding regime, growth potential, body weight and age of slaughtered cattle (Młynek et al. 2006; Enderr 2008). Such characteristics of meat as tenderness, water retention capacity, colour or acidity are related to the structure of intravitally developed muscles (Młynek et al. 2006; Keady et al. 2007) and have an enormous importance for the consumer and the processing industry.

The aim of this study was to identify the influence of growth intensity of bulls on musculus longissimus lumborum microstructure characteristics and verify whether growth intensity affects the metabolic profile, meat acidification and incidence of quality defects.

\section{Materials and Methods}

The study was performed on 43 hybrids (the mean age was 566 days), crosses of Polish Lowland black-andwhite breed cows (BW) in which the gene share of the Holstein Friesian breed did not exceed $25 \%$ with bulls of Charolais breed (CHAR) $(n=22)$ or Limousine breed (LIM) $(n=21)$. Bulls were kept under similar conditions but came from different farms. Fattening started when the calves weighed $150-180 \mathrm{~kg}$.

Address for correspondence:

Dr hab. Krzysztof Młynek

Departament of Cattle Breeding and Milk Evaluation

Faculty of Life Sciences, Siedlce University of Natural Science and Humanities

B. Prusa 14 st, 08-110 Siedlce, Poland 
In terms of gain and fattening time, growth intensity was calculated $\left(\mathrm{GI}_{\mathrm{g} / \mathrm{dav}}\right)$. Bulls were divided into two groups: bulls with grow intensity of $<900 \mathrm{~g} /$ day and bulls with grow intensity $\geq 900 \mathrm{~g} /$ day. In the autumn-winter period, animals from the first group were fed hay ad libitum and corn silage (approximately $10 \mathrm{~kg} / 24 \mathrm{~h}$ ). In the summer, green fodder and straw were provided at libitum. Compound cereal meal was used as a supplement to the main diet for animals in the second group at approximately $1.0 \mathrm{~kg} / 24 \mathrm{~h}$ throughout the fattening.

After a 24-h rest, the bulls were weighed and then slaughtered according to slaughterhouse procedures. Samples for histochemical analysis were collected within $30 \mathrm{~min}$ after slaughter, from the middle part of musculus longissimus lumborum. Samples were immediately cut into $1 \times 1 \times 1 \mathrm{~cm}$ pieces (parallel to the muscle fibres) and frozen using liquid nitrogen.

The cryopreparations were made using the SHANDON OT cryostat at $-25^{\circ} \mathrm{C}$ and cut into $10 \mu \mathrm{m}$-thick slices. The muscle microstructure assessment was conducted according to the method analysing the enzymatic activity of fibres (Dubovitz et al. 1973). Histochemical analysis differentiated muscle fibres into Slow-twitch Oxidative (STO), Fast-twitch Oxidative-Glycolytic (FTO) and Fast-twitch Glycolytic (FTG). Fibres STO (night-blue) and FTO (blue) were identified based on tetrazole dehydragenase activity (NADH-TR) after preincubation in a $\mathrm{pH} 4.0$ buffer with NADH. Grey-dyed FTG fibres were identified based on myofibrillar ATP-ase activity after incubation in a $\mathrm{pH} 9.6$ buffer.

Analysis of the muscle microstructure profile was performed based on the measurements recorded for 10 randomly selected fascicles of each muscle. The analysis included measurements of muscle fibre cross section area $\left(\mu \mathrm{m}^{2}\right)$ and calculations of mean fragmentation area $\left(\mu \mathrm{m}^{2}\right)$ and mean fibre type distribution (\%). Using the area and frequency of fibre types, the relative area of fibre type was determined and then the aerobic $-\mathrm{AF} \%=[(\mathrm{STO}+\mathrm{FTO}) / \mathrm{FTG}]$ and anaerobic indices $-\mathrm{AnF} \%=[(\mathrm{FTG}+\mathrm{FTO}) / \mathrm{STO}]$ were calculated.

The presence of glycogen (\%) in tissue was determined based on the histochemical periodic acid-schiff colour reaction. Taking advantage of colour intensity increase with rising glycogen (Śrutek and Kłosowska 2005). The assay technique consisted of analysing the microscopic image and measuring colour intensity.

The acidity in tissue was proceeded $24 \mathrm{~h}\left(\mathrm{pH}_{24}\right)$ and $48 \mathrm{~h}\left(\mathrm{pH}_{48}\right)$ post mortem.

The muscle structure and glycogen content were identified on the basis of images obtained with OLYMPUS BX41 compatible with the OLYMPUS Soft Imaging System - Cell ${ }^{\mathrm{B}}$.

Statistical data were processed with STATISTICA 9.0, providing the following: mean values $(\overline{\mathrm{X}})$, standard deviations (SD) and values for variance analysis in a non-orthogonal design. The population profile included evaluation of differences between the following mean values: slaughter weight, age and daily weight gains in the genetic groups under analysis. A model allowing for growth intensity was used for the analysis of the microstructure and the metabolic indices. The significance of differences was assessed using the Duncan multiple range test $(P \leq 0.01, P \leq 0.05)$

\section{Results}

Data presented in Table 1 show that in the case of the slaughter weight, age and growth intensity, differences between commercial hybrids were small and non-significant. On the other hand, significant differences $(P \leq 0.05)$ were confirmed for the values of slaughter indicators between animal categories with different growth intensities.

Animals with weight gains of 992 and $973 \mathrm{~g} /$ day (the $\geq 900 \mathrm{~g} /$ day category) had $70 \mathrm{~kg}$ greater body weights with the average body weight of $517.2 \mathrm{~kg}$ and were younger by about 79 days (the mean age was 526.6 days).

Table 1. Characteristics of slaughter indices and daily body gain of bulls $(\overline{\mathrm{X}} \pm \mathrm{SD})$

\begin{tabular}{|c|c|c|c|c|c|c|}
\hline \multirow{3}{*}{$\begin{array}{l}\text { Growth } \\
\text { intensity } \\
\text { categories } \\
\text { (g/day) }\end{array}$} & \multicolumn{6}{|c|}{ Slaughter indices } \\
\hline & \multicolumn{2}{|c|}{ Slaughter weight (kg) } & \multicolumn{2}{|c|}{ Age (day) } & \multicolumn{2}{|c|}{$\begin{array}{c}\text { Growth intensity } \\
\text { (g/day) }\end{array}$} \\
\hline & $\mathrm{BW} \times$ & $\mathrm{BW} \times$ & $\mathrm{BW} \times$ & $\mathrm{BW} \times$ & $\mathrm{BW} \times$ & $\mathrm{BW} \times$ \\
\hline (n) & $\begin{array}{l}\text { CHAR } \\
(22)\end{array}$ & $\begin{array}{l}\text { LIM } \\
(21)\end{array}$ & $\begin{array}{l}\text { CHAR } \\
(22)\end{array}$ & $\begin{array}{l}\text { LIM } \\
(21)\end{array}$ & $\begin{array}{l}\text { CHAR } \\
(22)\end{array}$ & $\begin{array}{l}\text { LIM } \\
(21)\end{array}$ \\
\hline$\leq 900(\mathrm{n}=19)$ & $445.0^{\mathrm{a}} \pm 37$ & $450.2^{a} \pm 55$ & $597^{a} \pm 32$ & $615^{a} \pm 24$ & $745^{a} \pm 42$ & $732^{a} \pm 51$ \\
\hline$\geq 900(\mathrm{n}=24)$ & $516.8^{b} \pm 44$ & $517.6^{b} \pm 38$ & $521^{b} \pm 21$ & $532^{b} \pm 41$ & $992^{b} \pm 35$ & $973^{b} \pm 44$ \\
\hline Total $(n=43)$ & $481.0 \pm 41$ & $483.9 \pm 45$ & $559 \pm 27$ & $573 \pm 32$ & $873 \pm 38$ & $852 \pm 47$ \\
\hline
\end{tabular}

BW - Polish Lowland black-and-white breed, CHAR - Charolais, LIM - Limousine breed

abc - significant differences in columns $(P \leq 0.05)$ 
Table 2. Characteristics $(\overline{\mathbf{X}} \pm \mathrm{SD})$ of microstructure of $\mathrm{m}$. longissimus lumborum in bulls in two different growth intensity categories

\begin{tabular}{|c|c|c|c|c|}
\hline \multirow[t]{2}{*}{ Estimation traits } & & \multicolumn{3}{|c|}{ Growth intensity categories (g/day) } \\
\hline & & $\leq 900(\mathrm{n}=19)$ & $\geq 900(\mathrm{n}=24)$ & Total $(n=43)$ \\
\hline \multicolumn{2}{|l|}{ Fibre number } & $35.3 \pm 4.3$ & $38.6 \pm 6.2$ & $36.9 \pm 5.3$ \\
\hline \multicolumn{2}{|l|}{ Mean fragmentation area $\left(\mu \mathrm{m}^{2}\right)$} & $1685^{\mathrm{A}} \pm 134$ & $1818^{\mathrm{B}} \pm 211$ & $1752 \pm 173$ \\
\hline \multirow[t]{3}{*}{ Cross section area $\left(\mu \mathrm{m}^{2}\right)$ : } & STO & $1655 \pm 132$ & $1691 \pm 142$ & $1673 \pm 137$ \\
\hline & FTO & $1661^{\mathrm{a}} \pm 149$ & $1741^{b} \pm 199$ & $1701 \pm 174$ \\
\hline & FTG & $1741^{\mathrm{A}} \pm 121$ & $1922^{\mathrm{B}} \pm 293$ & $1832 \pm 207$ \\
\hline \multirow[t]{3}{*}{ Fibre types distribution $(\%)$ : } & STO & $22.2^{\mathrm{A}} \pm 1.4$ & $20.1^{\mathrm{B}} \pm 2.5$ & $21.2 \pm 1.9$ \\
\hline & FTO & $19.5^{\mathrm{a}} \pm 1.8$ & $20.8^{b} \pm 3.5$ & $20.1 \pm 2.6$ \\
\hline & FTG & $58.3^{\mathrm{a}} \pm 1.7$ & $59.1^{\mathrm{b}} \pm 4.5$ & $58.7 \pm 3.1$ \\
\hline \multicolumn{2}{|l|}{ Number of giant fibre (n) } & NF & $1.2 * \pm 0.6$ & - \\
\hline \multicolumn{2}{|l|}{ Frequency of giant fibre (\%) } & NF & $2.9 * \pm 0.4$ & - \\
\hline
\end{tabular}

NF - not found; *9 animals, STO - Slow-twitch oxidative, FTO - Fast-twitch oxidative-glycolytic, FTG - Fasttwitch glycolytic.

Significant differences in rows: abc $P \leq 0.05,{ }^{\mathrm{ABC}} P \leq 0.01$.

Table 3. Characteristics ( $\overline{\mathbf{x}} \pm \mathrm{SD}$ ) of metabolism, amount of glycogen and $\mathrm{pH}$ in $\mathrm{m}$. longissimus lumborum of two growth intensity categories of bulls

\begin{tabular}{lccc}
\hline Traits & \multicolumn{3}{c}{ Growth intensity categories $(\mathrm{g} /$ day $)$} \\
\hline & $<900(\mathrm{n}=19)$ & $\geq 900(\mathrm{n}=24)$ & Total $(\mathrm{n}=43)$ \\
$\mathrm{AF}(\%)$ & $0.743^{\mathrm{a}} \pm 0.135$ & $0.622^{\mathrm{b}} \pm 0.122$ & $0.683 \pm 0.128$ \\
AnF $(\%)$ & $3.613^{\mathrm{a}} \pm 0.157$ & $3.874^{\mathrm{b}} \pm 0.173$ & $3.744 \pm 0.165$ \\
Glycogen $(\%)$ & $56.86^{\mathrm{A}} \pm 4.51$ & $51.14^{\mathrm{B}} \pm 3.71$ & $54.00 \pm 4.11$ \\
$\mathrm{pH}_{24}$ & $5.78^{\mathrm{A}} \pm 0.15$ & $5.97^{\mathrm{B}} \pm 0.69$ & $5.88 \pm 0.42$ \\
$\mathrm{pH}_{48}$ & $5.57^{\mathrm{a}} \pm 0.10$ & $5.63^{\mathrm{b}} \pm 0.49$ & $5.60 \pm 0.30$ \\
\hline
\end{tabular}

$\mathrm{AF}$ - aerobic indices, $\mathrm{AnF}$ - anaerobic indices

Significant differences in rows: ${ }^{\mathrm{abc}} P \leq 0.05,{ }^{\mathrm{ABC}} P \leq 0.01$.
Table 2 shows the results for changes in the microstructure of $\mathrm{m}$. longissimus lumborum of bulls in the two growth intensity categories. It can be seen that the mean fibre area of the more intensively growing animals was larger by $133 \mu \mathrm{m}^{2}$ $(P \leq 0.01)$. The difference in the size of the determined fibre types predominantly concerned fibres with myofibrillar ATPase activity (FTG); the difference amounted to $181 \mu \mathrm{m}^{2}(P \leq 0.01)$.

A slightly smaller difference of $80 \mu \mathrm{m}^{2}(P \leq 0.05)$ was identified for FTO fibres. Growth intensity also influenced the developing proportions between the fibre types. Muscles of the intensively growing bulls had a smaller (by about 2.2\%) share of fibres with active dehydrogenase. Differences in the share of the anaerobic (both FTO and FTG) fibres were not so prominent and ranged from 0.8 to $1.3 \%$.

The greatest variability in the cross-section area (SD of 199 and 293) and percentage share (SD of 3.5 and 4.5) was identified for anaerobic (FTG) and intermediary (FTO) fibres. This suggests that the muscles of the animals in the $\geq 900 \mathrm{~g} /$ day category contained fibres with greater cross-section areas than the population average. This theory was eventually confirmed by the data in Table 2 that show the presence of giant fibres in the more intensively growing animals. Such fibres were found to be present in 9 muscles $(37.5 \%)$ of all the muscles in this category of bulls.

Further effect of growth intensity on the bull muscle metabolism, acidity and major meat quality criteria are shown in Table 3.

The aerobic and anaerobic indices show predominance of anaerobic metabolic transformations consisting of muscle glycogen break-up in the muscles of the intensively growing animals. In comparison with the muscles of the bulls whose daily weight gain (group $\leq 900$ ) ranged from 745 to $732 \mathrm{~g}$ /day, $30 \mathrm{~min}$ after slaughter the glycogen content 
in the muscular tissue of the intensively growing animals (group $\geq 900$ ) was lower as evidenced in less intense redness (\%) of the preparations. The relevant value was lower by 5.71 units. The microstructure changes and lower glycogen supply resulted in lower acidification of the muscles in this group: $\mathrm{pH}_{24}=5.97(P \leq 0.01)$ and $\mathrm{pH}_{48}=5.63(P \leq 0.05)$.

The results of standard deviation obtained for the $\mathrm{pH}$ of the meat of the intensively growing bulls with giant fibres $\left(\mathrm{SD}=0.69\right.$ for $\mathrm{pH}_{24}$ and 0.49 for $\mathrm{pH}_{48}$ ) suggest typical acidity of dark firm and dry meat. Therefore, this part of research requires further analyses to specify whether the lower meat acidity was exclusively associated with excessive hypertrophy.

\section{Discussion}

The diet and postnatal changes in the muscular tissue significantly affect beef quality development and the efficiency of increasing the carcass meat content. According to Ashmore et al. (1974) and Wegner et al. (2000), an essential role in this respect is played by the share of fibres with different metabolism. The influence of fibre structure (the share of FTG fibres) on meat acidity was also observed by Rehfeldt et al. (2000). Kim et al. (2000) reported that meat acidification does not entirely depend on the glycogen content but also on the share of glycolytic fibres. They found that the acidification of $\mathrm{m}$. psoas major $\left(\mathrm{pH}_{24}=5.61\right)$ was faster than that of $\mathrm{m}$. longissimus dorsi $\left(\mathrm{pH}_{24}=5.73\right)$ which contained less glycogen but had a greater share of glycolytic fibres. Vestergaard et al. (2000) and Młynek et al. (2006) have reported a similar pattern.

Hoch et al. (2005) revealed a higher share of fast glycolytic (FG) fibres in the $\mathrm{m}$. triceps brachii (55.8-57.4\%) of intensively growing animals (from 884 to $975 \mathrm{~g} / \mathrm{day}$ ). The percentage share of these fibres in the less intensively growing animals (558$698 \mathrm{~g} /$ day) ranged from 54.5 to $55.5 \%$, while their activity of lactate dehydrogenase and isocitrate dehydrogenase was significantly lower. A similar pattern in the development of the percentage share of fibres with different enzymatic activity was suggested by Ouali (1990), Wegner et al. (2000) or Młynek and Guliński (2007).

Ozawa et al. (2000) did not confirm a direct effect of growth intensity on the postslaughter meat acidity profile. However, they identified significant correlation between growth intensity and fibre structure and size. The greatest aW fibre diameter $(55.6 \mu \mathrm{m})$ and share $(53.4 \%$ ) was identified in animals whose weight gain amounted to $0.69 \mathrm{~kg} /$ day. The above researchers observed a negative correlation $(\mathrm{r}=-0.31)$ between the magnitude of daily weight gains and meat acidification in the case of these fibres.

A major quality discriminant of meat is its $\mathrm{pH}$ which largely depends on post-slaughter glycogenolytic processes. According to Immonen et al. (2000), $45 \mathrm{mmol} / \mathrm{kg}$ of glycogen reduces the $\mathrm{pH}$ of meat from 7.2 to 5.5. Glycogen accumulation efficiency depends on individual characteristics. However, it is also affected by the feeding quality and preslaughter conditions (stress).

As shown in a study by Vestergaard et al. (2000), more intensively fed bulls slaughtered at lower body weight have, as a rule, higher glycogen content. The authors also proved that an extensive feeding regime is conducive to an increase of aerobic metabolism and higher activity of lactic acid dehydrogenase.

On the other hand, results obtained by Wegner et al. (2000) and Młynek and Guliński (2007) indicate a greater share and increased oxidative activity of muscle fibres in older cattle. Ashmore (1974) and Young and Foote (1984) suggested that a high oxidative metabolic activity of fibres can lead to lower acidity and a darker meat colour, both associated with the DFD defect.

In the case of cattle, faster glycolysis is more common in more muscular and heavier animals. Additionally, a greater share of glycolytic fibres facilitates pre-slaughter glycogen break-up and inhibits lactic acid accumulation after slaughter. This may suggest that more 
intensively growing animals are prone to faster glycogen depletion and lower meat acidity after slaughter.

In conclusion, enhancing growth intensity of commercial hybrids derived from Charolais and Limousin bulls is associated with changes in the cross section area and the share of fibres with higher myofibrillar ATPase activity. The changes result in predominance of anaerobic metabolism and smaller glycogen accumulation in the muscles of intensively growing animals.

\section{References}

Ashmore CR, Tompkins G, Doerr L 1974: Phenotypic expression of muscle fibre types and some implications to meat quality. J Anim Sci 38: 1158-1164

Dubowiz V, Brooke MH, Neville HE 1973: Muscle Biopsy. A modern approach. Ed. By W.B. Saunders, Company Ltd., London, Philadelphia, Toronto

Enderr K 2008: Growth and breed related changes of muscle fibre characteristics in cattle. J Anim Sci 78: 14851496

Hoch T, Jurie C, Pradel P, Cassar-Malek I, Jailler R, Picard B, Agabriel J 2005: Effects of hay quality on intake, growth path, body composition and muscle characteristics of Salers heifers. Anim Res 54: 241-257

Immonen K, Ruusunen M, Puolanne E 2000: Some effects of residual glycogen concentration on the physical and sensory quality of normal $\mathrm{pH}$ beef. Meat Sci 55: 33-38

Kim KH, Kim YS, Lee YK, Baik MG 2000: Posmortem muscle glycolysis and meat quality characteristics of intact male Korean native (Hanwoo) cattle. Meat Sci 55: 47-52

Klont RE, Brocks L, Eikelenboom G 1998: Muscle fibre type and meat quality. Meat Sci 49: 219-229

Keady TWJ, Lively FO, Kilpatrick DJ, Moss BW 2007: Effects of replacing grass silage with either maize or whole-crop wheat silages on the performance and meat quality of beef cattle offered two levels of concentrates. Anim Sci 1: 613-623

Młynek K, Elminowska-Wenda G, Guliński P 2006: The relationship between microstructure of longissimus lumborum muscle and carcass quality of bulls slaughtered at three ages. Anim Sci Pap Rep 24: 57-63

Młynek K, Guliński P 2007: The effect of growth rate and age at slaughter on dressing percentage and colour, pH48 and microstructure of longissimus dorsi muscle in Black-and-White (BW) bulls vs commercial crossbreds of BW with beef breeds. Anim Sci Pap Rep 25: 65-71

Ouali A 1990: Meat ageing: biological factors of variation. (in French). Viandes Produits Carnes 11: 281-290

Ozawa S, Mitsuhashi T, Mitsumoto M, Matsumoto S, Itoh N, Itagaki K, Kohno Y, Dohgo T 2000: The characteristics of muscle fiber types of longissimus thoracis muscle and their influences on the quantity and quality of meat from Japanese Black steers. Meat Sci 54: 65-70

Rehfeldt C, Fiedler I, Dietl G, Ender K 2000: Myogenesis and postnatal skeletal muscle cell growth as influenced by selection. Liv Prod Sci 66: 177-188

Śrutek M, Kłosowska D 2002: PAS histochemcal reaction-based evaluation of muscle glycogen content in turkeys using microscopic image analysis. Roczn Nauk Zoot 16: 31-36

Vestergaard M, Oksbierg N, Henckel P 2000: Influence of feeding intensity, grazing and finishing feeding on muscle fibre characteristics and meat colour of semitendinosus, longissimus dorsi and supraspinatus muscles of young bulls. Meat Sci 54: 177-185

Wegner J, Albrecht E, Fiedler I, Teuscher F, Papstein H J, Ender K 2000: Growth and breed-related changes of muscle fibre characteristics in catlle. J Anim Sci 78: 1485-1496

Young OA, Foote DM, 1984: Further studies on bovine muscle composition. Meat Sci 11: 159-170 